\title{
Room Allotment Management to Increase Room Occupancy and its Implication to Hotel Management Strategy
}

\author{
Vanny Oktafia Putri Rama 1 , I Ketut Astawa², I Gusti Made Wendri³ I I Gede Mudana ${ }^{4}$ \\ Tourism Business Management, Politeknik Negeri Bali \\ email: ${ }^{1}$ vannyopr@gmail.com, ${ }^{2}$ ketutastawa@pnb.ac.id, ${ }^{3}$ gustimadewendri@pnb.ac.id \\ ${ }^{4}$ gedemudana@pnb.ac.id
}

\begin{abstract}
In the tourism industry, fluctuations in room occupancy are common. Many hotels offer various types of accommodation and service options needed by guests, causing competition between one hotel and another hotel. The purpose of this study is to find out how the management of room allotment in an effort to increase room occupancy at a one 5-star hotel in the southern part of Bali. This study was conducted using a qualitative descriptive method with analysis of POAC (Planning, Organizing, Actuating, Controlling) and SWBR (Strength, Weakness, Benefit, Risk). Data is obtained using the interview method. This study also explains how the implications of room allotment management on management strategy at the hotel. The results of this study indicate that the management of the allotment room has been done quite well but has not provided maximum results in increasing room occupancy. The implications of giving room allotment based on management functions indicate that negotiations still have problems with the prices determined, there are strengths, weaknesses, benefits and risks in organizing the people who regulate the room allotment, the room allotment given has not been $100 \%$ fulfilled and there is no a special system to control room allotment. Future research is recommended with regard to the effectiveness of room allotment through the system.
\end{abstract}

Keywords: room allotment, management strategy, room occupancy, POAC management function, SWBR analysis.participation, millennial generation, national politics.

\section{INTRODUCTION}

In the world of hospitality, of course there have been fluctuations in demand for accommodation services due to the large number of accommodation services that offer more benefits such as cheaper prices and more profits. In order to be able to maintain the occupancy rate of its rooms, the hotel cooperates well with various travel agents in terms of room sales. According to Bagyono (2014: 60), a Travel Agent is a commercial business activity that regulates, and organizes services aimed at a person or group of people, which is carried out entirely with the main purpose of the tour and to gain profit.

The collaboration between the hotel and the travel agents are written in an agreement or contract that has been approved by the hotel with a travel agent better known as the contract rate that contains room prices, children policy, payment policy, cancellation policy, special promo and room allotment policy and various kinds of regulations that must be fulfilled by both parties. In many cases, travel agents have paper contract agreements with a particular hotel or other travel Supplier for Special confidential rates and room allotment guarantees, which usually give the travel agent a much cheaper rate compared with GDS (Global Distribution System) rates (Liman, $\mathrm{H}$. 
2005). The hotel gives room allotment to several travel agents which contributed in increasing room occupancy so that the travel agents were motivated to sell rooms using the room allotment given. According to Khairunas, S., \& Versia, F (2018) room allotment is amount of room allocate in a hotel. According to Soenarno (2013: 15), the allotment is a quota to get a number of rooms or facilities at the hotel for travel agents. Furthermore, according to Echols and Shadily (2010:21) allotments are parts, rations, gifts. In providing room allotment, everything is prepared with good management starting from planning, organizing the people involved in it, implementing it to controlling it. John D. Millet (Sukarna, 2011: 2), states that management is the process of directing and facilitating the work to people in formal group to achieve a desired end.

George R. Terry (Sukarna, 2011: 10) divides the four basic functions of management, namely Planning, Organizing, Actuating and Controlling. These four management functions are abbreviated as POAC. According to Dakhi, Y (2016), the POAC function itself in an organization is to increase effectiveness and the efficiency of an organization in achieving its goals. George R. Terry (Sukarna, 2011: 10) suggests about planning as follows "Planning and relating of facts and making and using of assumptions regarding future in the visualization and formulation to propose of proposed activation is believed to be large to achieve desired result". George R. Terry (Sukarna, 2011: 38) suggests about organizing as follows "Organizing the determining, grouping and arranging of various activities needed for attainment of the objectives, the assigning of the people to these activities, the providing of suitable physical factors and the relative authority delegated to each respective activity. According to George $R$. Terry (Sukarna, 2011: 82) said that actuating is setting all members of the group to want to achieve and to strike to achieve the objective of willing and keeping with managerial planning and organizing efforts. According to George R. Terry (Sukarna, 2011: 110) suggests that Controlling, i.e.: Controlling can be defined as the process of determining what is to accomplished, that is the standard, what is being accomplished. That is the performance, evaluating the performance, and if the necessary applying corrective measure so that performance takes place according to plans, that is conformity with the standard.

There are several obstacles in the implementation of the room allotment, so management strategies are needed to overcome them. Mulyasa (2012) said that strategic management aims to drive internal organization operations in the form of allocation of human, physical and financial resources to achieve optimal interaction with the external environment.
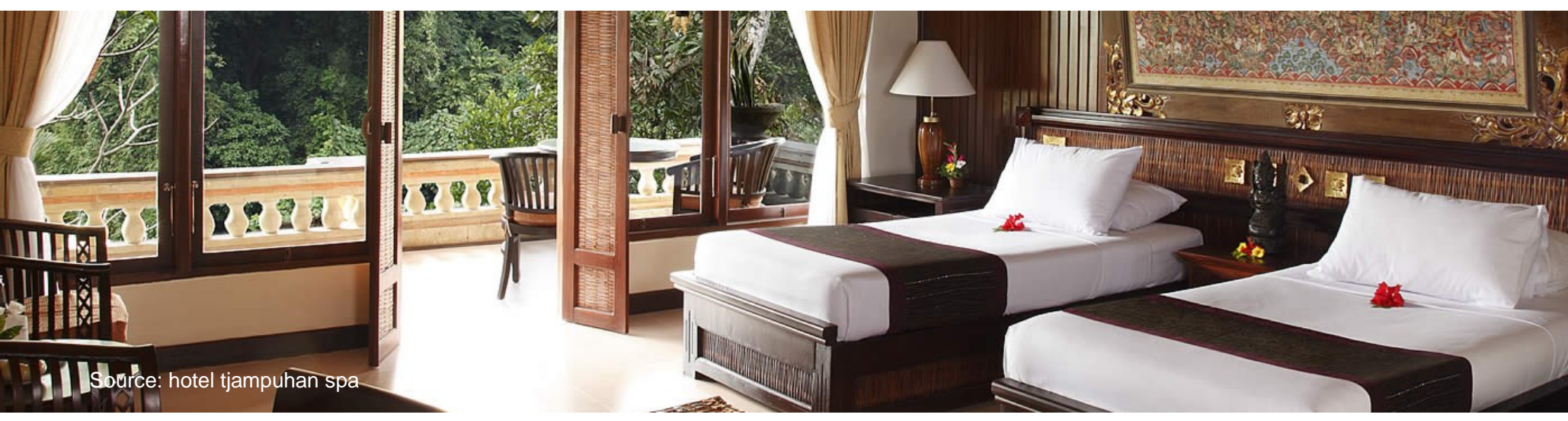


\section{RESEARCH METHOD}

The research objects are room allotment management, management strategy and room occupancy at the 5-star hotel stated above. This research uses qualitative and quantitative data. The sources of data in this research are primary data which is obtained through interviews with Senior Sales Manager Japan Market at the hotel regarding the room allotment management in an effort to increase room occupancy and the implication to management strategy, and secondary data which are the room allotment data and room occupancy data at the hotel. The data analysis technique used in this research is descriptive qualitative analysis. According to Nasution in Sugiyono (2013: 333), analysis begins since formulating and explaining the problem, before going to sitework and continues until the writing of research results. Descriptive qualitative analysis using the function of POAC (Planning, Organizing, Actuating, and Controlling) management and SWBR (Strength, Weakness, Benefit, and Risk) analysis in this research that will be carried out by the process of collecting and compiling data obtained through an in-depth interview, observation and other documents which related with room allotment at the hotel. POAC analysis is an analysis used to analyze all forms of events that occur to assess the potential and existing marketing systems through Planning, Organizing, Actuating, and Controlling (Parma, 2018).

\section{RESULTS AND DISCUSSION}

\section{The Implementation of Room Allotment Management in an Effort to Increase Room Occupancy through POAC Approach}

The result of the in-depth interview with Senior Sales Manager Japan Market at the hotel is as follows:

1. Planning

Planning includes establishing an allotment contract that was agreed by both parties between the hotel and a travel agent that is expected to be able to be fulfilled by both parties to make a profit. In planning this room allotment there are various things arranged by Senior Sales Manager Japan market. However, the application of the room allotment at the hotel until December 2018 is relatively flexible and not yet fully implemented.

2. Organizing

In running a room allotment, who plays a role and is involved in it is a Senior Sales Manager as the only person in charge of planning, monitoring and controlling the running of the room allotment.

3. Actuating

In the implementation, room allotment is usually given in a certain amount depending on how much the travel agent contributes to the hotel, starting from 2 rooms to the largest reaching 15 rooms per day. If the travel agent is able to fulfill the room allotment given, there will be more room allotments to be given to the travel agent in the future. However, if the travel agent cannot fulfill the room allotment that has been given or can only fulfill a small portion of the room allotment provided, there is no compensation or penalty in any form, but if this happens for a long time and even the travel agent cannot fulfill the room allotment given, consideration will be made and the number of room allotments to be given will be reduced and the other worst thing is the Sales and Marketing team will be able to 
terminate the contract with the travel agent if the travel agent considered completely unable to provide profits and increase room occupancy at the hotel.

4. Controlling

Senior sales managers in supervising room allotment always maintain good communication with the travel agent, both by telephone and e-mail, and often meet directly at the hotel and outside the hotel to discuss cooperation contracts. However, in its implementation, there were an obstacle at the hotel which did not have a special system to control room allotment, and so far, the implementation was still in a manual condition so that in this supervision the senior sales manager supervised and assessed how the room allotment works manually without a system.

\section{The Effect of Room Allotment Management to Room Occupancy}

In hotel industry, the main indicator of success depends largely on the occupancy rate (Abdullah, A. A., \& Haan, M. H. 2012). It is measured by the number of rooms booked divided by the number of room available (Bardi, 2007). The room occupancy at the hotel for the last 36 months during the period of January 2016 December 2018, generally fluctuated or experienced a constant increase or decrease every month. The lowest room occupancy occurred in November 2017, with only 104 room nights, this is because in November is low season so the room allotment that is fulfilled not too much therefore the number of guests decreased. On the other hand, the highest room occupancy is in August 2017 which the room occupancy reaching 257 room nights, this is because in August it is high season so many guests come to Bali. Moreover, in August is a celebration of Obon and Summer Vacation for Japanese people, therefore many Japanese tourists come on vacation in Bali. The room allotment influence the room occupancy, however the contribution of room allotment to room occupancy is not too much, the room occupancy is not only affected by room allotment, fluctuation in room occupancy at the hotel can also be affected by high season, low season, peak season, group, travel warnings from various countries and many other reasons.

\section{Management Strategy from the Aspect of Planning}

From the beginning of the establishment of the room allotment which described earlier in the planning chart, difficult thing found is negotiation. Travel agent often want a cheaper price than the set price by asking for more profits. This is a challenge for the Senior Sales Manager, but with his ability to negotiate, he is able to explain that the hotel is one of the 5-star hotels that is able to compete with other hotels and explains that the price given is worth it as what the guest will get many benefits when they stay at the hotel. The negotiation ability of the Senior Sales Manager with the travel agent is the strategy in making decisions and planning to achieve its goal of increasing room occupancy.

\section{Management Strategy from the Aspect of Organizing}

Senior Sales Manager Japan Market in managing room allotment based on SWBR analysis (strength, weakness, benefit and risk) can be explained as follows:

1. Strength 
A Senior Sales Manager as the only person who determines and controls the implementation of the room allotment can execute or decide anything about his own room allotment so there is no need to wait for someone else to give an opinion and negotiate what the next step therefore, the decision made can be determined quickly and supervision can be done easily.

2. Weakness

One-way communication that causes the Senior Sales Manager unable to receive input or other opinions from other parties, by doing all his own work, dividing the time to do other work will be difficult, and all work is only known by the Senior Sales Manager himself without anyone knowing it so that all of the tasks focus on the Senior Sales Manager and if he is unable to carry out his duties then no one else can replace or cover it.

3. Benefit

As the only determinant and executor of room allotment, there will be no conflict in making decisions and it will be pressing company costs because it only places oneperson, Senior Sales Manager who is truly competent in his field.

4. Risk

A big responsibility will be borne fully by the Senior Sales Manager if a problem occurs, the only one who controls is the Senior Sales Manager himself and the possibility of making a mistake will be greater because all the work is done by himself.

\section{Management Strategy from the Aspect of Actuating}

There are obstacles in implementing room allotment, this happened because the room allotment contract agreement is still flexible so there is no compensation for travel agents which could not fulfill the room allotment that had been given and the hotel could release a room allotment given to the travel agent anytime especially when the room fully booked. Actually, this situation provides benefits for both parties because travel agents do not have to pay any fees if they cannot fulfill the room allotment that has been given to them and the hotel also does not suffer losses because the hotel can take back the room allotment that has been given to travel agents anytime if needed. On the other hand, sometimes this situation causes problem, there are some travel agents who insist and do not want the room allotment that has been given to be taken back even though they are also unable to sell the room allotment but at that time the hotel has also informed travel agent side by sending stop sale, then the Senior Sales Manager will discuss it carefully with the travel agent side so that they will return the room allotment given so that the hotel can sell the room allotment to the walk-in guest or last minute booking. This decision was agreed by both parties as a win-win solution for both of them to get a common goal.

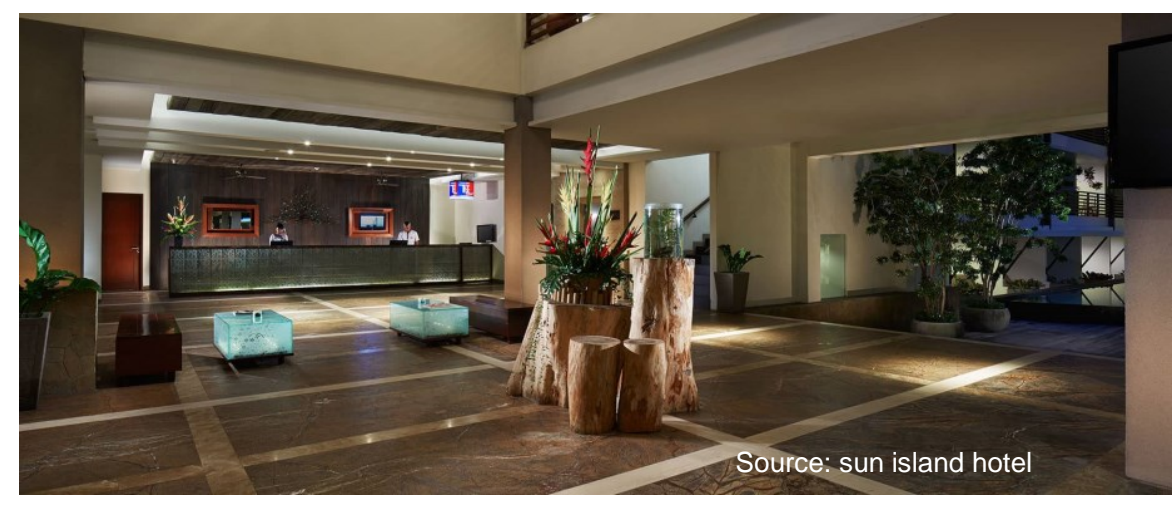




\section{Management Strategy from the Aspect of Controlling}

Room allotment cannot always be fulfilled $100 \%$, therefore, monitoring the extent of the room allotment must be carried out properly. The obstacle experienced by the hotel until now is there is no special system to control the running of the room allotment. Manually the Senior Sales Manager controls the room allotment using the Opera by checking how many rooms have been booked by the travel agent in one day and how many remaining room allotments they have. The room allotment will always be controlled to find out how far the travel agent can fulfill it and provide direct feedback to the travel agent, and see whether the fulfillment of the room allotment year by year increases or decreases. How to control it is by finding the name of the travel agent in the source column or company in the reservation that was made that day.

\section{CONCLUSION}

Referring to the result of the data analysis it can be concluded that room allotment management at the hotel start from planning, organizing, actuating, and controlling has been applied quite well but still experiencing some obstacles. In planning room allotment, there was still obstacles at the beginning which is how to negotiate with the travel agent and how to win the negotiation with them. Senior Sales

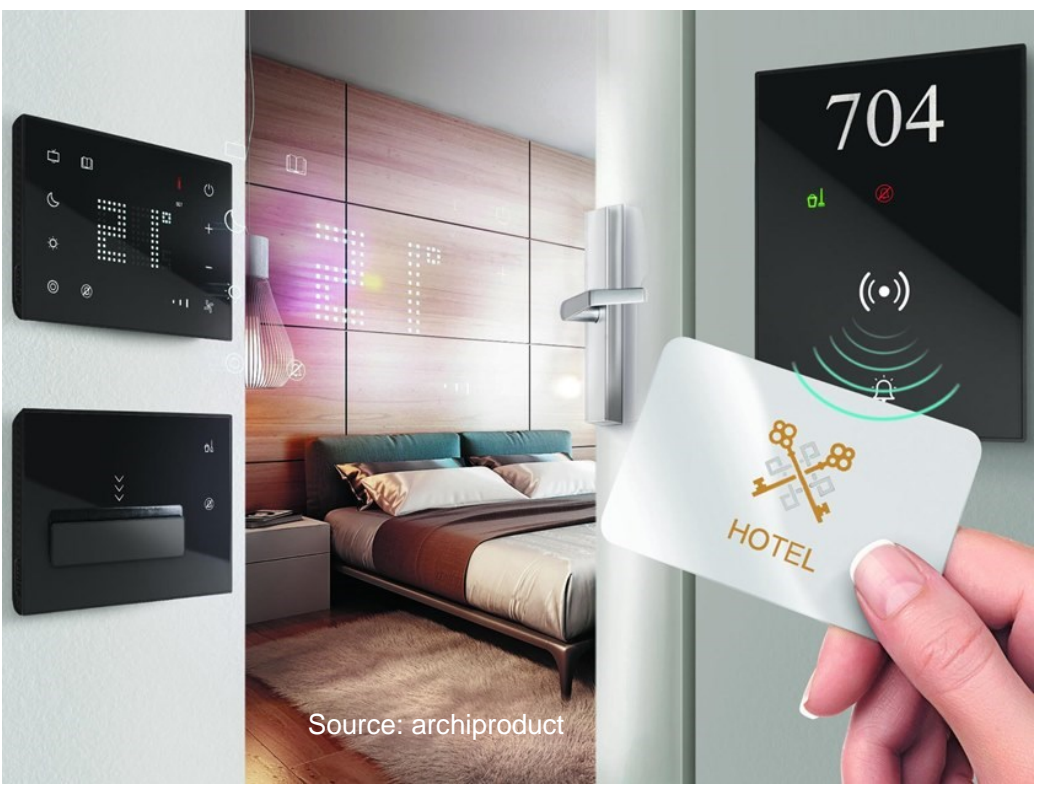

control the room allotment. The room allotment management affect the enhancement of room occupancy at the hotel however, it is not maximal enough. However, the management strategy carried out by the hotel was able to handle all the problems and obstacles that occurred in the implementation of the room allotment so that until now the room allotment is still managed well even though it is not maximal enough in increasing room occupancy at the hotel.

\section{REFERENCES}

Abdullah, A. A., \& Haan, M. H. 2012. "Internal success factor of hotel occupancy rate. International Journal of Business and Social Science", 3(22).

Bagyono. 2014. Pariwisata dan Perhotelan. Bandung: Alfabeta 
BARDI, J.A. 2007. "Hotel Front Office Management". New Jersey: Wiley, 2007. ISBN 978-0-471-68710-8.

Dakhi, Y. 2016. “Implementasi Poac terhadap Kegiatan Organisasi dalam Mencapai Tujuan Tertentu", Warta Dharmawangsa, (50).

Echols, John M \& Hassan Shadily. 2010. Kamus Inggris-Indonesia. Jakarta: PT Gramedia Pustaka Utama.

Khairunas, S., \& Versia, F. 2018. "English Expressions and Terminologies Used for Reservation In PT. Raja Kamar Indonesia Jakarta". Wanastra: Jurnal Bahasa dan Sastra, 10(1), 42-49.

Liman, H. 2005. U.S. Patent Application No. 10/613,383.

Mulyasa, E. 2012. Manajemen dan Kepemimpinan Kepala Sekolah. Jakarta: Bumi Aksara.

Parma, I. P. G., Ariana, I. N. J., Putri, I. A. T. E., Putra, A. M., Sulistyawati, A. S., Suarka, F. M., ... \& Widiantara, I. G. A. B. 2018. Jurnal Perhotelan dan Pariwisata Triatma Jaya, Juli-Desember 2017. Sekolah Tinggi Pariwisata Triatma Jaya, 7(2), 1-139.

Soenarno, A. 2003. Kamus Istilah Pariwisata \& Perhotelan. Angkasa.

Sukarna. 2011. Dasar-dasar Manajemen. CV. Mandar Maju. Bandung

Sugiyono, M. P. K. 2013. Kualitatif dan Kombinasi (Mixed Methods). Bandung: Alfabeta. 
82 | Vanny Oktafia Putri Rama, I Ketut Astawa, I Gusti Made Wendri, I Gede Mudana 